\title{
Cryoglobulinemic vasculitis as a rare complication of rheumatoid arthritis : a case report
}

\section{Gaukhar Bakhtiyarova, Mehtap Tinazlı \\ Near East University, School of Medicine, Internal Medicine Department. Near East Avenue, Nicosia- Northen Cyprus Turkish Republic.}

his work is licensed under a Creative Commons Attribution $\mathbf{4 . 0}$ International License

Received: 15.06.17

Accepted: 23.07.17

UDC: 616.1

\section{J Clin Med Kaz 2017;4(46):37-39}

Автор для корреспонденции: Gaukhar Bakhtiyarova, Near East University, School of Medicine, İnternal Medicine Department. Near East Avenue, PK:99138, Nicosia- Northen Cyprus Turkish Republic, Mersin 10 Turkey. E-mail: gypocrat@mail.ru. Tel: +90-5338639659, Fax: $+90-392-2293096$.

\section{Abstract}

Cryoglobulinemic vasculitis (CV); is a disease characterized by cryoglobulin-containing immunodeposits that often involve small vessels of the skin and glomeruli. It is considered to be a rare disorder. There are few cases identified in patients with rheumatoid arthritis (RA) suffering from immunological disorders such as Sjogren's Disease and infectious agents such like as human immunodeficiency virus (HIV) or hepatitis C virus (HCV) infection. We wanted to share a case where we think of cryoglobulinemic vasculitis with rheumatoid arthritis at 50 years old. He applied to us with cyanosis fingertips and severe pain in his hand. Clinical features were assessed by laboratory and nailfold capillaroscopy and CV was diagnosed. Then the patient was treated with intravenous Iloprost for 5 consecutive days, nifedipin and antiagregan. Clinically, the patient presented with a significant reduction of pain and decrease of fingertips ulsers after the second monthly treatment.

Keywords: Cryoglobulinemia - vasculitis - rheumatoid arthritis.

\section{РЕВМАТОИДТЫ АРТРИТТЫН СИРЕК АСҚЫНУЫ РЕТІНДЕ КРИОГЛОБУЛИНЕМИЯЛЫК ВАСКУЛИТ:} КЛИНИКАЛЫҚ ЖАҒДАЙ.

Гаухар Бахтиярова, Мехтап Тиназли

Таяушығыс универститетінің Медицина факультеті,

Ішкі аурулар кафедрасы, Никосия, Солтүстік Кипр

\section{ТҰЖЫРЫМДАМА}

Криоглобулинемиялык васкулит (КВ) көбінесе терінің майда тамырларымен шумактарды қамтитын құрамында криоглобулины бар иммунодепозиттерімен сипатталатын аурудың бір турі. Бұл сирек кездесетін бұзылыс болып саналалы. Ревматоидты артриты (РА), иммунологиялык бузылыстардан зардап шегетін, Шегрен ауруы сияқты және де инфекциялық агенттерден, адамның иммундық тапшылық вирусы (ВИЧ) немесе гепатит С вирусы (HCV) сияқты наукастарда анықталған өте сирек көріністері.

Біздің 50 жастағы РА мен криоглобулинемиялык васкулиты бар клиникалық жағдаймен бөліскіміз келді. Науқас емханамызга қолындағы ауырсыну сезімімен және саусақ ұштарының цианозы шағымдарымен келді. Клиникалық ерекшеліктерін зертханалық және тырнақ капилляроскопиясы көмегін бағаланды. КВ диагнозы қойылды. Науқас 5 күн бойы Илопростол, нифедипин және антиагреганттармен емделді. Науқаста емінін 2ші айынан кейін саусақ ұштарындағы жаралары мен ауырсыну сезімінін азаюы байқалды.

\section{КРИОГЛОБУЛИНЕМИЧЕСКИЙ ВАСКУЛИТ КАК РЕДКОЕ ОСЛОЖНЕНИЕ РЕВМАТОИДНОГО АРТРИТА: КЛИНИЧЕСКИЙ СЛУЧАЙ \\ Гаухар Бахтиярова, Мехтап Тиназли \\ Медицинский факультет Ближневосточного университета, кафедра внутренних болезней, Никосия, Северный Кипр}

\section{PЕЗЮМЕ}

Криоглобулинемический васкулит является заболеванием, характеризующееся криоглобулин-содержащими депозитами, которые часто повреждают мелки сосуды кожи и клубочки. Это считается редким поражением. Имеется мало выявленных случаев у пациентов с ревматоидым артитом, страдающих иммунологическими расстройствами, такими как болезнь Шегрена, инфекционными агентами, такими как вирус иммунодефицита человека или вирусного гепатита С.

Мы хотели поделиться клиническим случаем, мужчина 50 лет с РА у которого мы подозревали наличие криоглобуинемического васкулита. Он обратился к нам с наличием цианоза кончиков пальцев рук и сильной болью в руке.

Клинические признаки оценивали с помощью лабораторных данных и капилляроскопией ногтевого фаланга, где и был диагностирован криоглобуинемический васкулит.

После больному была проведена в/в терапия Илиопростом в течении 5 дней, нифедипином и антиагрегантами. Клинически после 2х месячного лечения, у пациента наблюдалось уменьшение язв в объеме на кончиках пальцев, а также уменьшение боли в руке.

Ключевые слова: криоглобулинемия - васкулит - ревматоидный артрит. 


\section{Introduction}

RA is a form of chronic inflammatory arthritis that progresses with marked extraarticular findings. It can affect people of all ages and vasculitis is the rare complication of RA. The risk of morbidity and mortality is high. It's a serious complication despite the aggressive use of the disease modifying therapy.(1). CV is a disease known as circulating cryoglobulin, which is characterized by the presence of skin purpura, fatigue and arthralgias. This rare disease is characterized by accumulation of different amounts in different organs and may affect the following systems that skin lesions (purpura, ulsers), peripheral neuropathy, membranoproliferative glomerulonephritis, chronic hepatitis, diffuse vasculitis and less frequently, endocrine disorders and intertitial lung involvement $(2,3)$. CV can also be seen with some immunological and infectious diseases that RA, Primary Sjögren's Syndrome, HCV, HIV. The diagnosis of this disease is based on clinical features and laboratory findings(4). Although the incidence of rheumatoid vasculitis had declined in recent decades, it was still a disease with high morbidity and mortality despite aggressive treatment. Hydroxychloroquine and low-dose aspirin appeared to play a protective role in this disease (1). The case on its association with RA in the absence of HCV, HIV infections or malignancy and other immunological disorders are limited.

\section{Case Report}

A 50-year-old man applied to our outpatient clinic with severe pain and bruising at his fingertips in the hand. He had been hospitalized in April 2015 for Raynaud phenomenon and painfull digital ulser. His reciped to artralgias and morning stiffness in finger joints. In physical examination : normal blood pressure and pulse rate, peripheral pulses were being taken. Cyanosis both hands, in right hand 3.metacarpophalangeal (MCP)joint was swollen and painful, 4. finger pulp digital ulcers in the left hand, and in the left hand 2. and 5. fingertips with necrotic areas in the left hand 2. distalinterphalangeal (DIP) joint flexion contracture were detected (Figure 1).

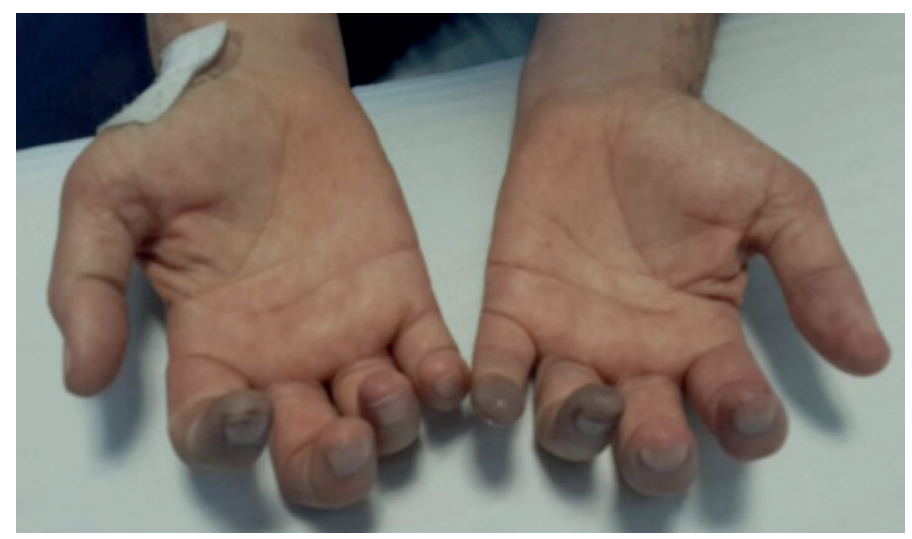

Figure 1 - Bilaterally hands Raynaud phenomenon and digital ulcer (before treatment)

The remaining systemic examination were normal. We evaluated with nailfold capilleroscopy : the capilleroscopic findings at the bazal time showing the presence of microhemorrhages, tortuosity, enlargement and derangement of capillaries and a few mega-capillaries. Laboratory tests showed normal serum renal, liver and tyroid test levels, and serological tests for hepatitis B, C and HIV virus were negative. Chest $\mathrm{X}$-ray was normal. Abnormal laboratory investigations included hemoglobin level 10,7 g/dL; leukocyte counted $11 \times 103 \mu \mathrm{L}$; thrombocyte counted $565 \times 103 \mu \mathrm{L}$; erythrocyte sedimentation rate (ESR): $80 \mathrm{~mm} / \mathrm{h}$ and C-reactive protein (CRP) level: 4.25 $\mathrm{mg} / \mathrm{dl}$.

Rheumatoid factor (RF) and serum cryoglobuline, cryofibrinogene were positive. Anti-nuclear antibodies were low positive. Antibodies to extractable nuclear antigens (ENA) were not identified. Anti-cyclic citrullinated peptide (CCP), anticardiyolipin antibodies, dsDNA were also negative. Urine test was normal. Pulmonary fonction test (PFT), diffusion lung carbonmonoxide test (DLCO) and echocardiography were normal. Hand - wrist radiographs of the MCP and proximalinterphalangeal ( PIP) joints were seen widespread erosion. Seropositive (erosive) arthritis was diagnosed according to American College of Rheumatology 1987 criteria. The patient was treated with intravenous Endoprost (Iloprost was produced by Italfarmaco Spa) at a dosage of $1 \mathrm{ng} / \mathrm{kg} / \mathrm{min}$ for 5 concecutive days and monthly. The patient was receiving treatment during the first visit: methotrexate $15 \mathrm{mg} /$ week, prednisone $8 \mathrm{mg} /$ day, folic acid $1 \mathrm{mg} /$ day and calcium+vitamin $\mathrm{D}$, pentoxifylline 800 mg/day, Acetylsalicylic Acid $100 \mathrm{mg} /$ day, nifedipine $30 \mathrm{mg} /$ day.

Clinically, the patient presented with a significant reduction of pain and decreased of fingertips ulcers after the second monthly treatment (Figure 2).

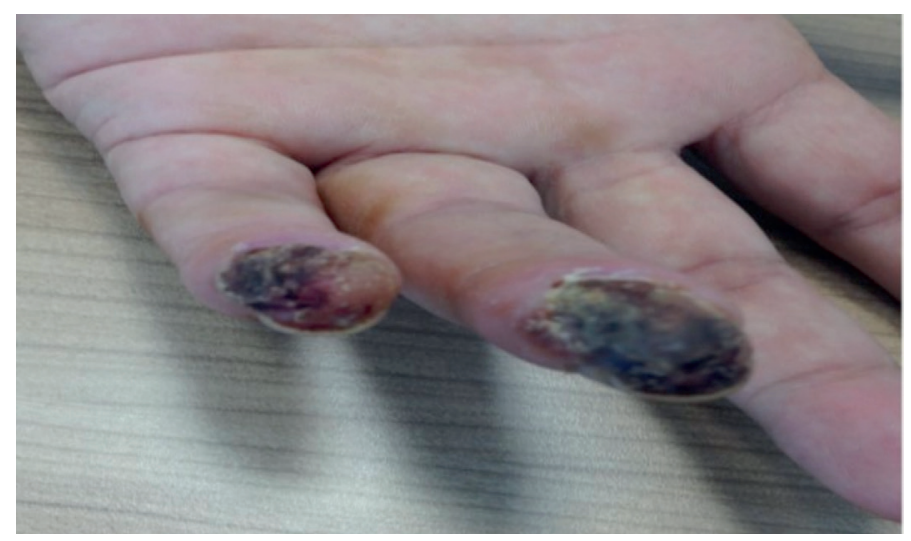

Figure 2 - During treatment

The patient responded favorably treatment and general care and, at the time of this writing, had no recurrences digital ulcers (Figure 3).

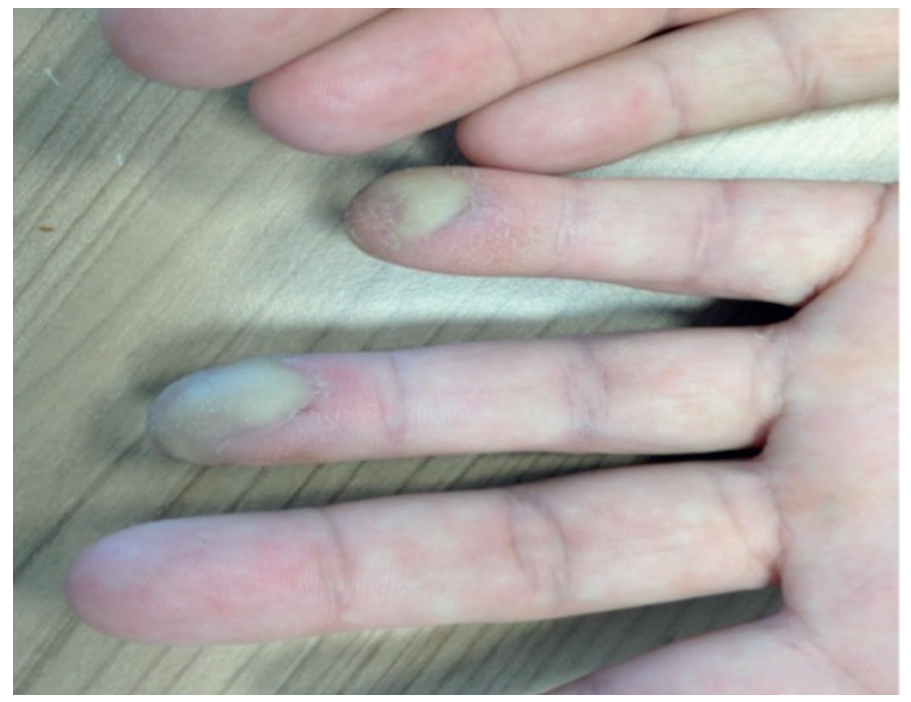

Figure 3 - After treatment 


\section{Discussion}

RA is systemic autoimmune rheumatic disorder with progressive evolution, leading to disability and increases mortality. The cause is still unknown, although many enviromental and individual factors precipitate the onset of disease (5). Rheumatoid vasculitis may present a heterogeneous clinical course. The clinical manifestations of this disease are deep cutaneous ulcers, vasculitic neuropathy, peripheral gangrene inflammatory eye disease and visceral infarction All have been associated with poor clinically reflections (6). CV or other names mixed cryoglobulinemia is also considered to be a rare disorder and same time a rare complication of RA.

Occasionally, lymphatic and hepatic malignant developments may occur as late complications in some patients. The etiopathogenesis of $\mathrm{CV}$ is unknown. $\mathrm{HCV}$ infection can be the cause of $\mathrm{CV}$ in the presence of certain genetic and environmental factors. In addition, CV may be associated with infectious agents such as HIV and immunological diseases such as Primer Sjogren's Syndrome. Diagnosis is based on clinical and laboratory findings. Because of the clinical and histological features are similar, $\mathrm{CV}$ can be considered as a subgroup of small vessel vasculitis (4). According to the best of our knowledge, there are few cases described in patients with rheumatoid arthritis (RA) that do not suffer from Hepatitis C virus (HCV) infection, HIV infection and some immunological disorders, such as primary Sjögren's syndrome (4).

Our patient, is 50-year-old, male sex who had RA diagnosis 5 years ago but had no regular follow-up and treatment. Symptoms included pain and stiffness in his hands small joints, Raynaud and digital ulcers in his fingertips. There were elevated levels of erythrocyte sedimentation rate and CRP in laboratory tests. The immunological test detected positive rheumatoid factor and positive cryoglobulinemia. The radiograph of the hands demonstrated loss of joint space and erosions of the proximal and distal interphalangeal joints compatible with rheumatoid arthritis in our patients. In patients past medical history there was smoking for ten years 1.5 pack of cigarettes daily.

According to literature, male sex, smoking, for a long time of RA history, presence of rheumatoid nodules and additionally HLA class I and II genotypes have been associated with an increased risk of rheumatoid vasculitis (6). The onset of the rheumatoid vasculitis clinic usually manifests itself as a systemic inflammatory response $(6,7)$. There were elevated ESR, CRP and anaemia in our patient. Leukocytosis and thrombocytosis were not always seen similar to previous studies. It is not necessary too. $(6,8)$.

Although such capilleroscopic findings share common features with a scleroderma-like pattern or sometimes Thromboangiitis obliterans (Buerger's disease), including the presence of mega-capiliaries and micro-hemorrhages, the absence of further clinical as well as serological data helped us to exlude a diagnosis of connective tissue disorders (9).

In this case study, we report the cryoglobulinemic vasculitis as a rare complication of rheumatoid arthritis. It should be considered by clinicians despite its rare occurrence. Because the consequences of this situation can be mortal. Therefore, the physician must be aware of the risk of vasculitis in patients with rheumatoid arthritis.

Informed Consent: Written informed consent was obtained from the patient.

Conflict of Interest: No conflict of interest was declared by the authors.

Financial Disclosure: The authors declared that this study has received no financial support.

\section{References}

1. Makol A, Matteson EL, Warrington KJ. Rheumatoid vasculitis: an update. Curr Opin Rheumatol. 2015; 27(1): 63-70.

2. Ferri C, Zignego AL, Pileri SA. Cryoglobulins (review) J Clin Pathol. 2002; 55: 4-13.

3. Brouet JC, Clouvel JP, Danon F, Klein M, Seligmann M. Biologic and clinical significance of cryoglobulins. Am J Med. 1974; 57: $775-88$.

4. Ferri C. Mixed cryoglobulinemia. Orphanet J Rare Dis. 2008; 3-25.

5. Sokolovic S, Dervisevic V, Fisekovic S. Mental health status can reflect disease activity in rheumatoid arthritis. Eur J Rheumatol 2014; $1: 55-7$.

6. Makol A, Crowson CS, Wetter DA, Sokumbi O,Matteson EL, Warrington KJ. Vasculitis associated with rheumatoid arthritis: a case-control study. Rheumatology (Oxford). 2014; 53(5): 890-899.

7. Turesson CM. Extraarticular features of rheumatoid arthritis and systemic involvement. In: Hochberg MC, et al., editors. Rheumatology. 4th edn. Philadelphia: Mosby; 2008. Pp. 773-83.

8. Scott DG, Bacon PA. Tribe CR. Systemic rheumatoid vasculitis: a clinical and laboratory study of 50 cases. Medicine. 1981; 60:288-9

9. Guidelli GM, Bardelli M, Fioravanti A, Selvi E. Nailfold capillaroscopy in Buerger's disease: A useful tool?. Eur J Rheumatol 2014; 1: 81-3.

How to cite this article: Gaukhar Bakhtiyarova, Mehtap Tinazli. Cryoglobulinemic vasculitis as a rare complication of rheumatoid arthritis: a case report. J Clin Med Kaz 2017;4(46):37-39 